\title{
Fullerene Polymers: A Brief Review
}

\author{
Peter J. F. Harris $\mathbb{B}$
}

Electron Microscopy Laboratory and Department of Chemistry, J.J. Thomson Building, University of Reading, Whiteknights, Reading RG6 6AF, UK; p.j.f.harris@reading.ac.uk

Received: 18 September 2020; Accepted: 3 November 2020; Published: 5 November 2020

\begin{abstract}
This paper reviews the ways in which $\mathrm{C}_{60}$ and other fullerene molecules can be incorporated into polymeric structures. Firstly, polymers in which the fullerenes are incorporated into the structure by covalent or noncovalent bonding are discussed. These include "pearl necklace" structures, "charm bracelet" structures, organometallic polymers, crosslinked polymers, end-capped polymers, star-shaped polymers and supramolecular polymers. Secondly, all-carbon polymers, which are produced by fusing fullerenes together, are covered. The synthesis and properties of each class of fullerene polymer are outlined and the prospects for commercial applications considered.
\end{abstract}

Keywords: fullerenes; $\mathrm{C}_{60}$; polymers

\section{Introduction}

Fullerenes and their derivatives have many remarkable chemical, electronic and optical properties, but to date, few of these properties have been exploited in commercial products. One reason is that $\mathrm{C}_{60}$ and the other fullerenes do not easily lend themselves to processing. The pure fullerenes are insoluble in water, which is a problem when it comes to potential applications in medicine and other areas. Although water-soluble fullerenes can be produced by functionalisation with groups such as $-\mathrm{COOH}$ and $-\mathrm{OH}$, the dissolved fullerenes have a tendency to clump together rather than remain as separate molecules. Moreover, in order to solubilise the fullerenes, it is often necessary to add more than one functional group. Not only can this change the chemical and physical properties of the carbon molecules, but the derivatised fullerenes often contain a mixture of regioisomers, and these are difficult to separate. An alternative approach which avoids some of these problems is to incorporate fullerenes into polymers. In many cases, a single attachment between the fullerene and the polymer is sufficient to create solubility in water. As well as making fullerenes soluble, incorporating them into polymers generally enhances the processibility of these extraordinary molecules, thus facilitating their application in a wide variety of areas.

Work began on the preparation of fullerene polymers shortly after the bulk synthesis of $C_{60}$ in 1990 [1]. Since that time, the study of these polymers has grown into a significant sub-discipline of fullerene science [2-6]. Many different kinds of polymer have been synthesised, including the so-called "pearl necklace", or main-chain, structures, in which the fullerene molecules are joined together with short bridging groups, as shown in Figure 1a, and the "charm bracelet", or side-chain, polymers, where the fullerenes dangle from the backbone of existing polymers, as in Figure 1b. Other structures in which fullerenes are linked to existing polymers include random crosslinked and end-capped ones. Organometallic $\mathrm{C}_{60}$ polymers, which can be one-, two- or three-dimensional, have been quite widely researched, while star-shaped polymers, in which a single fullerene molecule is joined to a number of polymer chains, have also been studied. Supramolecular polymers, where the fullerenes are incorporated into to the structure by weak intermolecular interactions rather than covalent bonds, have been prepared, and some have been shown to be soluble in water. 
a

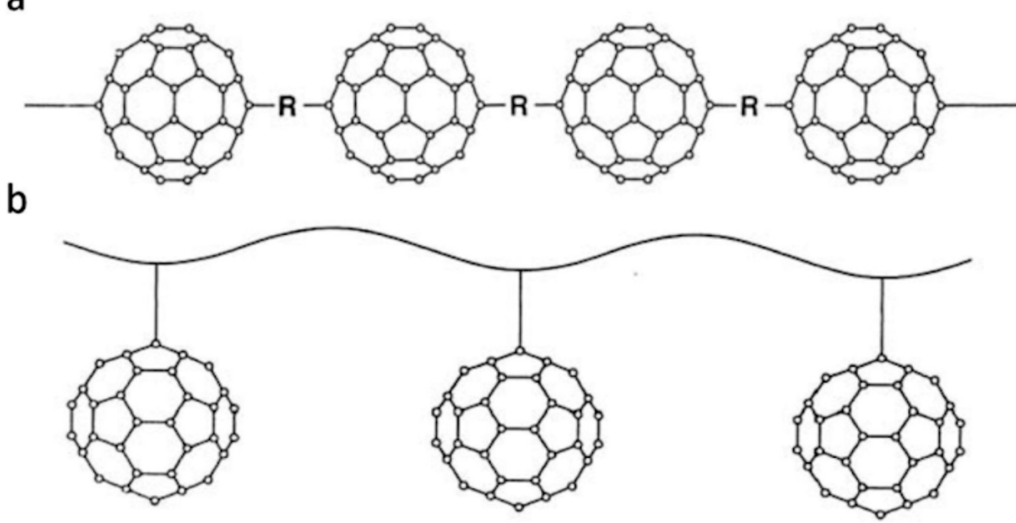

Figure 1. Schematic illustration of (a) pearl necklace polymer, (b) charm bracelet polymer. Adapted from [7].

A quite separate class of fullerene polymers is produced by fusing fullerenes together to form all-carbon polymers. These structures can have interesting electrical properties and they can display extreme hardness. The aim of the current article is to give a brief overview of the various forms of fullerene polymer, with references up to 2020 .

\section{Pearl Necklace Polymers}

An assembly consisting of two linked $\mathrm{C}_{60}$ molecules was synthesised by Wudl et al. in 1992 [8]. This could be considered the first step towards a pearl necklace polymer. The synthesis involved reacting $\mathrm{C}_{60}$ with the diazomethanes derived from m-phenylenebis(benzoyl) and p-phenylenebis(benzoyl). Early attempts to prepare extended pearl necklace polymers often resulted in intractable, insoluble mixtures, e.g., [9]. In 2000, Geckeler et al. reported the synthesis of the first water-soluble $\mathrm{C}_{60}$ main-chain polymer [10]. Here, the linking groups were shielded inside cyclodextrin cavities with the fullerene, as shown in Figure 2. They showed that the fullerene retained its ability to cleave DNA nucleotides via a singlet oxygen transfer at the guanosine base sequence when attached to this polymer.

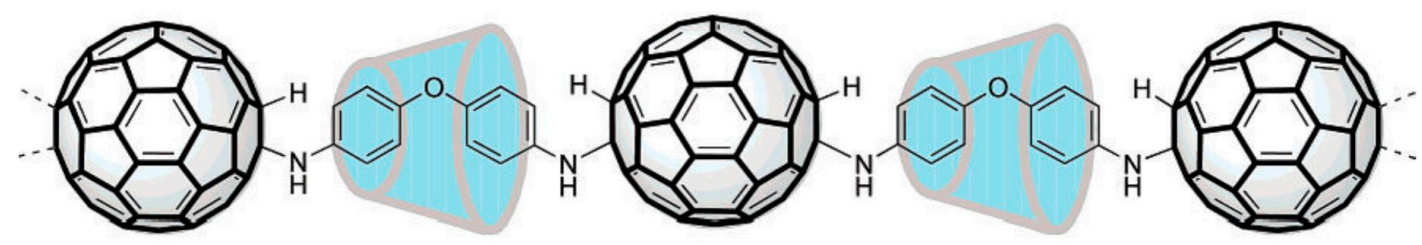

Figure 2. Water-soluble main-chain fullerene polymer with supramolecular cyclodextrin shielding of linking groups [10].

Main-chain $\mathrm{C}_{60}$ polymers have also been considered as components of photovoltaic devices. The fullerene derivative most frequently employed in such devices is phenyl- $\mathrm{C}_{61}$-butyric acid methyl ester (PCBM), but Hiorns and colleagues suggested that copolymers which incorporate fullerenes as alternating repeated moieties in a conjugated polymer structure might have advantages in this application [11-13]. The idea was that nanodomains of well-organised copolymers parallel to the electrodes might enhance interface interactions and increase current flow. This group prepared bis-benzyl $\mathrm{C}_{60}$ polymers through atom transfer radical addition (ATRA) of 1,4-bis(bromomethyl)benzene intermediate to the fullerene. A solar cell containing such a polymer was shown to have an efficiency of $4.2 \%$.

\section{Charm Bracelet Polymers}

It appears that the first charm bracelet $\mathrm{C}_{60}$ polymer was prepared by Olah et al. in 1991 [14]. This group showed that a $\mathrm{C}_{60} / \mathrm{C}_{70}$ mixture reacted with polystyrene under $\mathrm{AlCl}_{3}$ catalysis in $\mathrm{CS}_{2}$ 
to produce a highly crosslinked fullerenated polystyrene. A short time later, Wudl and colleagues attached $\mathrm{C}_{60}$ to polyester and polyurethane and showed that the fullerene molecules retained their electrochemical and non-linear optical properties when joined to the polymers [15]. Since this early work, charm bracelet, or side-chain, structures have become the most widely studied form of $\mathrm{C}_{60}$ polymers. Most of the common polymers have been functionalised with $\mathrm{C}_{60}$ in this way, including aminopolymers [16], polycarbonates [17], polysaccharides [18], polysiloxanes [19] and polyesters [20]. A popular method for attaching $\mathrm{C}_{60}$ to polymers has involved cycloaddition to azido groups on the polymer chains. Hawker prepared polystyrene- $\mathrm{C}_{60}$ polymers using this method in 1994 and demonstrated that the copolymer retained both the electronic properties of the fullerene and the solubility and processability of the polystyrene [21]. Other routes to charm bracelet $\mathrm{C}_{60}$ polymers include nucleophilic addition [15] and ATRA [22].

As well as attaching fullerenes to pre-existing polymers, charm bracelet polymers have also been prepared by catalysed polymerisation of fullerene-bearing monomers. One method which has become quite popular was introduced by Wudl and co-workers in 1995 [23]. This involved polymerising norbornene-modified $\mathrm{C}_{60}$, in the presence of an excess of norbornene and a catalyst, using ring-opening metathesis copolymerisation (ROMP), as shown in Figure 3. Other groups have subsequently used the technique [24,25].

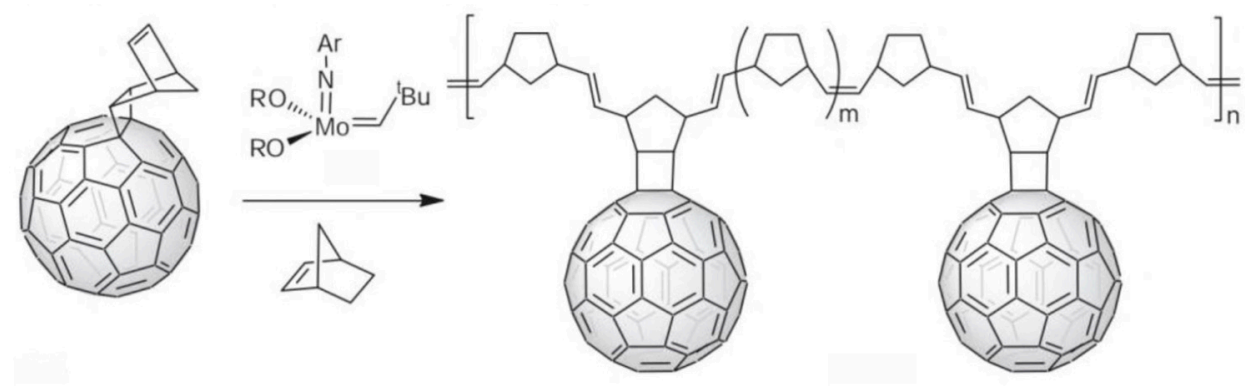

Figure 3. Polymerisation of norbornene-modified $C_{60}$ using ring-opening metathesis polymerisation $[4,23]$.

A number of charm bracelet $\mathrm{C}_{60}$ polymers with water solubility have now been prepared. In 2006, Iwamoto and Yamakoshi synthesised a $\mathrm{C}_{60}-\mathrm{N}$-vinylpyrrolidone (NVP) copolymer using radical polymerisation [26]. This was found to have one of the highest water-solubilities $(7.8 \mathrm{mM})$ of any fullerene derivative. In 2014, the same authors, with colleagues, prepared a soluble $\mathrm{C}_{60}$-polyvinylpyrrolidone (PVP) copolymer and investigated its ability to generate photoinduced reactive oxygen species [27]. A Russian group prepared fullerene-containing copolymers using radical polymerisation in 2017 [28]. They suggested that the copolymers might find applications as photo- and electroactive materials.

It was noted above that main-chain $\mathrm{C}_{60}$ polymers with potential use in solar cells have been prepared. Side-chain polymers have also been prepared with this application in mind. Block co-polymers have often been favoured, owing to their tendency to self-assemble into ordered structures. In 2005, Drees, Sariçiftçi and colleagues described the synthesis of the fullerene derivative, $\mathrm{C}_{61}$-butyric acid glycidol ester (PCBG), which they then polymerised [29]. Introducing this into the poly(3-hexylthiophene) (P3HT) active layer resulted in a network of fullerene molecules dispersed throughout the bulk, thus avoiding the issues with aggregation that can result when individual molecules of phenyl- $\mathrm{C}_{61}$-butyric acid methyl ester (PCBM) are used in such cells. The device produced in this way had an energy conversion efficiency of $2 \%$. Other groups have prepared side-chain $\mathrm{C}_{60}$ polymers for photovoltaic devices, e.g., [30,31]. Polymerisable $\mathrm{C}_{70}$ derivatives have also been considered for this application [32].

\section{Organometallic Polymers}

Organometallic $\mathrm{C}_{60}$ polymers have attracted significant interest. The first example of such a polymer was a pearl necklace structure synthesised in 1992 by Nagashima and colleagues [33]. By mixing 
$\mathrm{C}_{60}$ with $\mathrm{Pd}_{2}(\mathrm{dba})_{3}$, where dba is dibenzylideneacetone), with 1:1 stoichiometry, these workers obtained a linear $\mathrm{C}_{60} \mathrm{Pd}$ polymer. They also showed that changing the $\mathrm{Pd}: \mathrm{C}_{60}$ ratio or heating the one-dimensional polymer could produce three-dimensional polymers. Since this early work, many further polymers with fullerenes covalently bonded to palladium, platinum and other transition metals have been synthesised, e.g., [34-36]. The polymers can be one-, two- or three-dimensional. Figure 4, from work by Leng et al. [36], shows a linear organometallic polymer. A theoretical analysis of the interactions between Pd and fullerenes in polymers has been given by Goclon and colleagues, who found that the most stable polymer structure is one in which the $C_{60}$ s are bonded via the $[6,6]$ position of the fullerene molecules with Pd in a distorted tetrahedral coordination [37]. Organometallic $\mathrm{C}_{60}$ polymers may have potential applications in catalysis [34,38], electrochemistry, e.g., [7,35], and other areas.

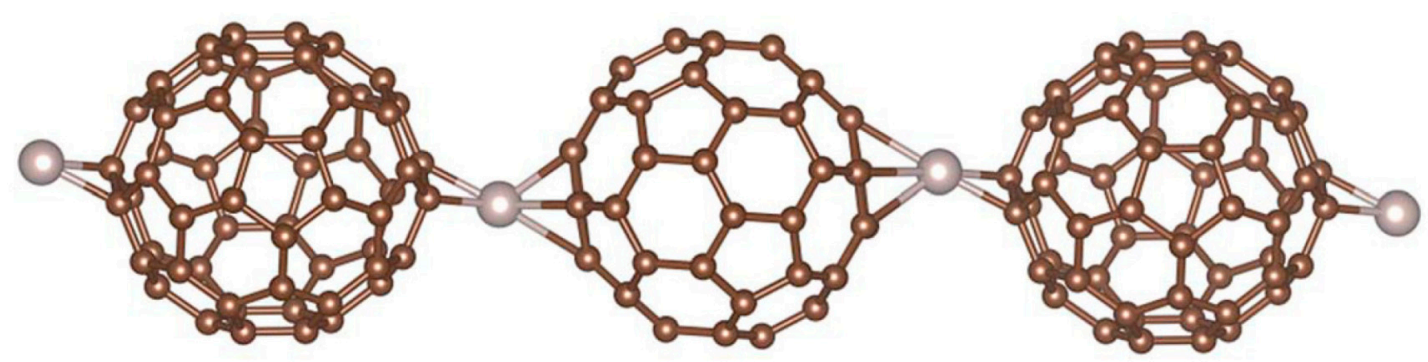

Figure 4. One-dimensional $\mathrm{Ru}-\mathrm{C}_{60}$ polymer. $\mathrm{Ru}$ atoms are in grey [36].

\section{Crosslinked Polymers}

Many of the early attempts to prepare extended pearl necklace and charm bracelet polymers resulted in intractable, crosslinked mixtures, e.g., [9]. However, a few groups have succeeded in introducing some control into the synthesis of crosslinked polymers in order to prepare potentially useful products. A schematic illustration of a crosslinked $C_{60}$ polymer is shown in Figure 5a. In 2016, Sugawara et al. described the preparation of crosslinked polymer-fullerene networks by reacting a tetrazole-functionalised polymer with $\mathrm{C}_{60}$ under UV irradiation [39]. They suggested that the networks may have applications in bulk heterojunction solar cells. Chen and colleagues synthesised a crosslinked composite by reacting $\mathrm{C}_{60}$ with an aromatic poly-amide with pendent furan groups [40]. They demonstrated improved high-temperature shape memory behaviour of the composite compared to the pure polymer. As a final example, Zhou et al. incorporated $\mathrm{C}_{60}$ into the conducting polymer poly(3,4-ethylenedioxythiophene) (PEDOT), with the aim of producing photoresponsive thermoelectric materials [41].
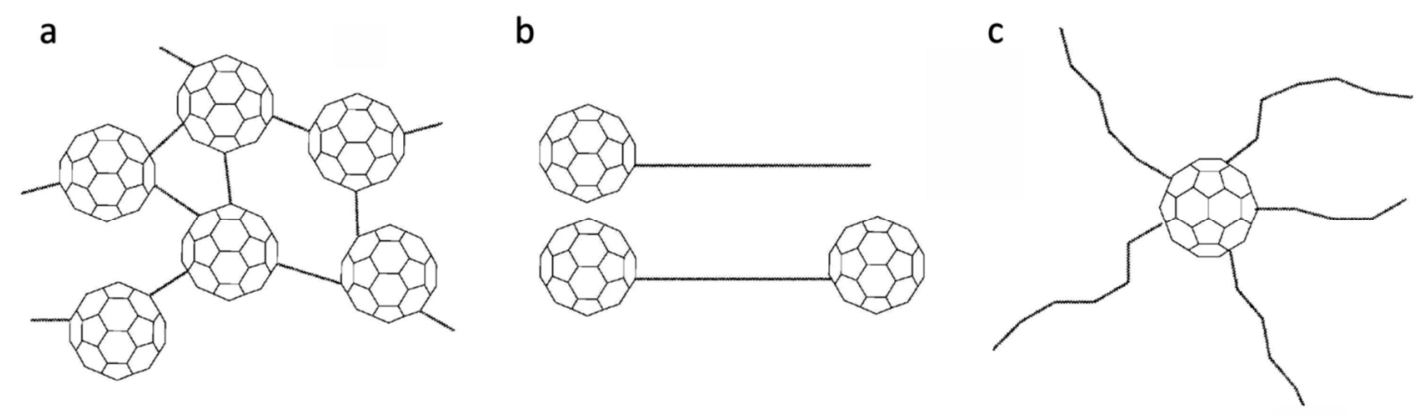

Figure 5. Schematic illustrations of (a) crosslinked $\mathrm{C}_{60}$ polymer, (b) end-capped polymers, (c) star-shaped polymer [2].

\section{End-Capped Polymers}

End-capped polymers are polymers with a fullerene bonded to one or both ends (see Figure $5 b$ ). An advantage here is that the exact number of fullerene molecules attached to the polymer is known: it is either one or two, as shown in Figure 5b, depending on the synthesis method. 
In 2010, Karsten and co-workers prepared diketopyrrolopyrrole-based small band gap oligomers, end-capped at both ends with $\mathrm{C}_{60}$ [42]. Upon photoexcitation of the oligomer, ultrafast energy transfer to the fullerene occurs, followed by an electron transfer reaction, suggesting that the assembly could be a useful component of photovoltaic devices. The synthesis of poly(ethylene glycol) end-capped with $\mathrm{C}_{60}$ was described by Jung et al. [43]. The polymer was added to the P3HT:PCBM active layer of a solar cell, resulting in enhanced performance and air stability of the cell. Hiorns and colleagues have also explored the application of end-capped fullerene polymers in solar cells [44]. In 2017, Topham and colleagues described a method of linking chains of poly(3,4-dimethoxystyrene), generated by reversible-addition fragmentation chain transfer (RAFT), polymerisation, to single $C_{60}$ molecules [45]. Their relatively simple approach should be applicable to the preparation of a wide range of different fullerene end-capped polymers.

\section{Star-Shaped Polymers}

The so-called star-shaped polymers usually consist of a single molecule $C_{60}$ joined to a number of polymer chains, as shown in Figure $5 \mathrm{c}$ [46]. The first such structures were prepared by Samulski et al. in 1992 [47], who attached between 1 and 10 linear polystyrene (PS) chains to C $_{60}$ to produce what they called "flagellenes". Their method involved reacting a living PS carbanion with $\mathrm{C}_{60}$. Ederlé and Mathis used a similar method in 1997 to produce polystyrene, polyisoprene and other $\mathrm{C}_{60}$ polymer stars [48]. In 2007, $\mathrm{Xu}$ and colleagues synthesised $\mathrm{C}_{60}$-cored star polyfluorenes by modifying the bromo end-groups of $C_{60}$ hexakisadducts using Suzuki polycondensation [49]. The resulting star-shaped polymers might be used as blue light-emitting materials. Another potential application for fullerene-containing star-shaped polymers might be as components of membranes for gas or water purification [50-52].

\section{Supramolecular Polymers}

In supramolecular polymers, the fullerenes are incorporated into the polymer by weak intermolecular interactions rather than covalent bonds. This has been used as a route to producing water-soluble fullerene materials. For example, in 2004, Liu and co-workers prepared the polymer shown in Figure 6, where $\mathrm{C}_{60} \mathrm{~s}$ are held within dimeric cyclodextrin units with coordinated metal centres [53]. Assemblies of 60-80 units were prepared and imaged by scanning tunnelling spectroscopy and transmission electron microscopy. The polymer was water-soluble and displayed DNA-cleavage ability under light irradiation. As with the work by Geckeler et al. mentioned above, the DNA-cleavage involves the generation of excited singlet molecular oxygen by the fullerene.

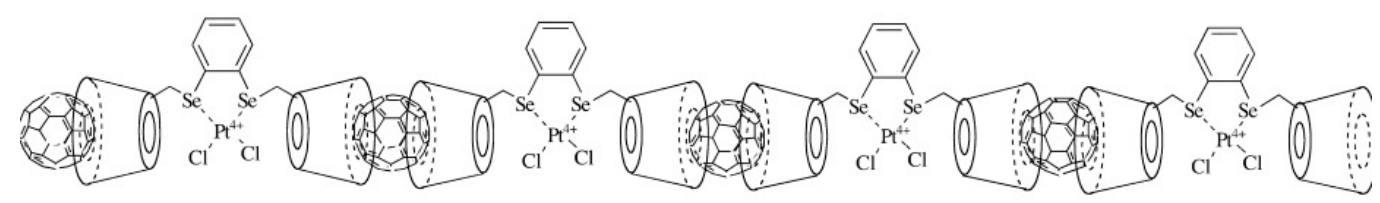

Figure 6. Supramolecular fullerene polymer mediated by metallobridged $\beta$-cyclodextrins, from Liu et al. [53].

In 2014, Isla and co-workers prepared supramolecular polymers from monomer units consisting of a $\mathrm{C}_{60}$ derivative and a 9,10-di(1,3-dithiol-2-ylidene)-9,10-dihydroanthracene (exTTF) macrocycle [54]. They reported a high degree of polymerisation, reaching molecular weights greater than $150 \mathrm{kDa}$ in solution, which was believed to be higher than any fullerene-based supramolecular polymer reported at that time. The authors suggest that these materials might find use in the construction of self-organised optoelectronic devices. Haino and colleagues have recently synthesised fullerene-terminated polymethyl methacrylates (PMMAs) and demonstrated that calix [5] arene hosts can bind to the fullerene moieties of the PMMAs, inducing interesting shape transformations in the polymers [55]. 


\section{All-Carbon Polymers}

As well as incorporating fullerenes into a polymer chain, or attaching them to a polymer via functional groups, it is also possible to prepare all-carbon fullerene polymers. This was first demonstrated by Rao, Eklund and co-workers in 1993 [56]. They showed that irradiating fcc $\mathrm{C}_{60}$ films, in the absence of oxygen, with visible or ultraviolet light produced a phase transformation. Analysis of the new structure showed that the fullerene molecules within the film had been photopolymerised. Work published in the following year showed that polymerisation could also be induced by the application of pressures above $1 \mathrm{GPa}$ at moderate temperatures [57]. A theoretical analysis of this process by a group from Grenoble suggested that it involves [2 +2$]$ cycloadditions between two 6-6 double bonds of neighbouring $\mathrm{C}_{60} \mathrm{~s}$ to form cyclobutene rings connecting the fullerenes, to form a one-dimensional chain, as shown in Figure 7a [58]. It is now established that a number of different polymeric phases, including two-dimensional and three-dimensional as well as one-dimensional, can be produced under different pressure and temperature conditions. Examples are shown in Figure 7. Davydov and colleagues have shown that there are two distinct one-dimensional phases, both orthorhombic: a phase formed at low pressure [59], which could be transformed to a new phase through the simultaneous action of pressure and X-rays [60]. At higher temperatures and pressures, two-dimensional phases form. There are two different phases of these: tetragonal and rhombohedral.

The application of still higher pressures, above $8 \mathrm{GPa}$, can result in the formation of 3D polymers, and these have been very widely studied, both experimentally and theoretically, e.g., [61-64]. In many cases, the poor crystallinity of the 3D polymers means that X-ray crystal structures have not been obtained. One structure which has been established is shown in Figure $7 \mathrm{~d}$. This was prepared by a group led by Yamanaka in 2006 by applying a pressure of $15 \mathrm{GPa}$ to $2 \mathrm{D} \mathrm{C}_{60}$ polymer single crystals at $600{ }^{\circ} \mathrm{C}$ [65]. Single crystal X-ray diffraction revealed that the 3D polymer crystallised in a body-centred orthorhombic structure, with the $\mathrm{C}_{60}$ monomer units substantially deformed to rectangular cuboidal shapes, each unit being bonded to eight cuboidal $C_{60}$ neighbours via [3+3] cycloaddition. The structure contains both $\mathrm{sp}^{3}$ and $\mathrm{sp}^{2}$ carbon atoms. The polymer shown in Figure 7e is taken from work by Marques and colleagues [66,67]. This is an fcc polymeric $\mathrm{C}_{60}$ phase obtained at $9.5 \mathrm{GPa}$ and $550{ }^{\circ} \mathrm{C}$. This phase was reported previously by Talyzin et al., but not structurally characterised [63]. Marques et al. carried out synchrotron diffraction studies of the polymer, coupled with Density Functional Theory (DFT) investigations, and found that whether or not neighbouring $\mathrm{C}_{60} \mathrm{~s}$ bonded with each other depended on their orientation. As a result, it is not possible to describe the polymer in terms of a defined crystallographic structure. Instead, they proposed a "frustrated" structure, where there is random bonding within the lattice while maintaining the cubic symmetry. Three-dimensional $C_{60}$ polymers have been shown to have a range of interesting properties. In contrast with the nonconductive behaviour of $2 \mathrm{D}$ polymers, $3 \mathrm{D} \mathrm{C}_{60}$ polymers are electrically conductive [65], and they can possess extreme hardness $[63,68]$. Research on $C_{60}$ polymers and on the effect of high pressures on fullerenes has been reviewed $[67,69]$. 


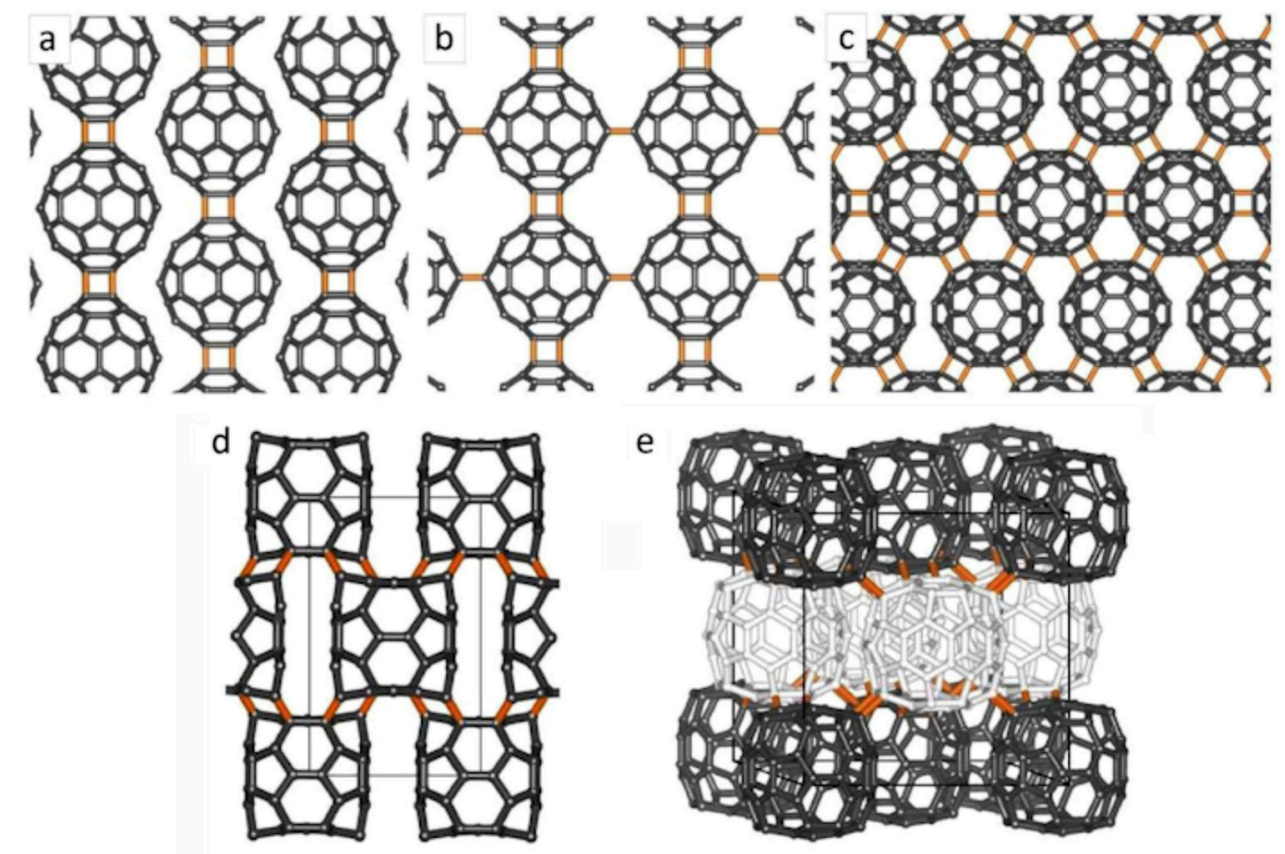

Figure 7. All carbon polymerised $\mathrm{C}_{60}$ structures. (a) 1D, (b) 2D-tetragonal, (c) 2D-rhombohedral, (d) 3D cuboidal, (e) 3D AuCuI-type. Adapted from [67].

\section{Discussion}

The fullerene polymers described in this paper could be divided into two broad classes. In the first class, covered in Sections 2-8, the fullerenes are incorporated into the polymers by covalent or noncovalent bonding. In the second category, covered in Section 9, the fullerenes are fused together in all-carbon structures. Great ingenuity has been shown by synthetic chemists in finding ways to prepare the first class of polymeric structures, and many different varieties have been synthesised. The simplest to prepare, and most widely studied, are the charm bracelet, or side-chain, polymers, where the fullerenes are attached to an existing polymer backbone. Many of the most common polymers have been modified in this way, since the pioneering work by Olah et al. in 1991 [14]. A number of charm bracelet polymers have been shown to be water-soluble; indeed, the system prepared by Iwamoto and Yamakoshi [27] was found to have one of the highest water-solubilities of any fullerene derivative. Among the potential applications of charm bracelet polymers has been in solar cells, where the use of a polymer enables the fullerene derivatives to be dispersed throughout the bulk, thus avoiding the issues with aggregation that can result when individual fullerene-based molecules are used. Pearl necklace or main-chain polymers, in which the fullerenes are joined together by linking groups, have not been as extensively studied as charm bracelet polymers, as they are more difficult to synthesise. However, several pearl necklace polymers have been prepared, and, like charm bracelet polymers, they have been considered as components of photovoltaic devices, as well as for other applications. The other members of the first type of fullerene polymers all have potentially useful applications. Thus, organometallic $\mathrm{C}_{60}$ polymers may be useful in catalysis and electrochemistry, while star-shaped polymers might be valuable as components of membranes for gas or water purification. Despite these many possible applications, however, it appears that there are no currently available commercial products which incorporate fullerene polymers. The reason may be the relatively high cost of these materials. The price of pure $\mathrm{C}_{60}$ is currently around USD 100 per gram, and the preparation of polymeric structures would add considerably to this cost. Until these prices can be reduced, the potential of fullerene polymers may continue to be unrealised.

Concerning all-carbon fullerene polymers, these are fascinating materials which continue to be the subject of intensive research. One-, two- and three-dimensional structures have been synthesised, and many more potential all-carbon polymers are possible. The polymers which have 
been produced display a wide range of electronic and of elastic properties, but, as with the other forms of polymer discussed here, the high cost of fullerenes remains a serious problem when considering commercial applications.

Funding: This research received no external funding.

Acknowledgments: I wish to thank Yamakoshi Yoko, Yingfeng Tu, Leonel Marques and Shoji Yamanaka for helpful advice and comments.

Conflicts of Interest: The author declares no conflict of interest.

\section{References}

1. Krätschmer, W.; Lamb, L.D.; Fostiropoulos, K.; Huffman, D.R. Solid $C_{60}$ : A new form of carbon. Nature 1990, 347, 354-358. [CrossRef]

2. Wang, C.; Guo, Z.-X.; Fu, S.; Wu, W.; Zhu, D. Polymers containing fullerene or carbon nanotube structures. Prog. Polym. Sci. 2004, 29, 1079-1141. [CrossRef]

3. Giacalone, F.; Martín, N. Fullerene polymers: Synthesis and properties. Chem. Rev. 2006, 106, 5136-5190. [CrossRef] [PubMed]

4. Giacalone, F. Fullerene-containing polymers. In Fullerenes: Principles and Applications, 2nd ed.; Puente, F.L.D.L., Nierengarten, J.-F., Eds.; Royal Society of Chemistry: Cambridge, UK, 2011; pp. 125-161.

5. Gradzka, E.; Wysocka-Żołopa, M.; Winkler, K. Fullerene-based conducting polymers: n-Dopable materials for charge storage application. Adv. Energy Mater. 2020, 10, 2001443. [CrossRef]

6. Ravi, P.; Dai, S.; Wang, C.; Tam, K.C. Fullerene containing polymers: A review on their synthesis and supramolecular behavior in solution. J. Nanosci. Nanotechnol. 2007, 7, 1176-1196. [CrossRef] [PubMed]

7. Winkler, K.; Balch, A.L. Electrochemically formed two-component films comprised of fullerene and transition-metal components. C. R. Chim. 2006, 9, 928-943. [CrossRef]

8. Suzuki, T.; Li, Q.; Khemani, K.C.; Wudl, F. Synthesis of m-phenylene- and p-phenylenebis(phenylfulleroids): Two-pearl sections of pearl necklace polymers. J. Am. Chem. Soc. 1992, 114, 7300-7301. [CrossRef]

9. Loy, D.A.; Assink, R.A. Synthesis of a fullerene $C_{60}$-p-xylylene copolymer. J. Am. Chem. Soc. 1992, 114, 3977-3978. [CrossRef]

10. Samal, S.; Choi, B.J;; Geckeler, K.E. The first water-soluble main-chain polyfullerene. Chem. Commun. 2000, 1373-1374. [CrossRef]

11. Raissi, M.; Erothu, H.; Ibarboure, E.; Bejbouji, H.; Cramail, H.; Cloutet, E.; Vignau, L.; Hiorns, R.C. Main-chain poly(fullerene) multiblock copolymers as organic photovoltaic donor-acceptors and stabilizers. J. Mater. Chem. A 2017, 5, 7533-7544. [CrossRef]

12. Stephen, M.; Dowland, S.; Gregori, A.; Ramanitra, H.H.; Santos Silva, H.; Combe, C.M.S.; Bégué, D.; Dagron-Lartigau, C.; Morse, G.E.; Genevičius, K.; et al. Main-chain fullerene and dye oligomers: Towards alternating fullerene polymers for organic photovoltaics. Polym. Int. 2017, 66, 388-398. [CrossRef]

13. Silva, H.S.; Ramanitra, H.H.; Bregadiolli, B.A.; Tournebize, A.; Bégué, D.; Dowland, S.A.; Chassé, T. In situ generation of fullerene from a poly(fullerene). J. Polym. Sci. Part B Polym. Phys. 2019, 57, 1434-1452. [CrossRef]

14. Olah, G.A.; Bucsi, I.; Lambert, C.; Aniszfeld, R.; Trivedi, N.J.; Sensharma, D.K.; Prakash, G.K.S. Polyarenefullerenes, $\mathrm{C}_{60}(\mathrm{H}-\mathrm{Ar}) \mathrm{n}$, obtained by acid-catalyzed fullerenation of aromatics. J. Am. Chem. Soc. 1991, 113, 9387-9388. [CrossRef]

15. Shi, S.; Khemani, K.C.; Chan, L.Q.; Wudl, F. A polyester and polyurethane of diphenyl $\mathrm{C}_{61}$ : Retention of fulleroid properties in a polymer. J. Am. Chem. Soc. 1992, 114, 10656-10657. [CrossRef]

16. Geckeler, K.E.; Hirsch, A.J. Polymer-bound C 60 . J. Am. Chem. Soc. 1993, 115, 3850-3851. [CrossRef]

17. Wu, H.; Li, F.; Lin, Y.; Cai, R.; Wu, H.; Tong, R.; Qian, S. Fullerene-functionalized polycarbonate: Synthesis under microwave irradiation and nonlinear optical property. Polym. Eng. Sci. 2006, 46, 399-405. [CrossRef]

18. Okamura, H.; Miyazono, K.; Minoda, M.; Miyamoto, T. Preparation of water-soluble pullulans bearing pendant $\mathrm{C}_{60}$ and their aqueous solubility. Macromol. Rapid Commun. 1999, 20, 41-45. [CrossRef]

19. $\mathrm{Li}, \mathrm{Z}$;; Qin, J. A new postfunctional method to synthesize $\mathrm{C}_{60}$-containing polysiloxanes. J. Appl. Polym. Sci. 2003, 89, 2068-2071. [CrossRef] 
20. Yan, H.; Chen, S.; Lu, M.; Zhu, X.; Li, Y.; Wu, D.; Tu, Y.; Zhu, X. Side-chain fullerene polyesters: A new class of high refractive index polymers. Mater. Horiz. 2014, 1, 247-250. [CrossRef]

21. Hawker, C.J. A simple and versatile method for the synthesis of $\mathrm{C}_{60}$ copolymers. Macromolecules 1994, 27, 4836-4837. [CrossRef]

22. Chen, X.; Gholamkhass, B.; Han, X.; Vamvounis, G.; Holdcroft, S. Polythiophene-graft-styrene and polythiophene-graft-(styrene-graft- $\mathrm{C}_{60}$ ) copolymers. Macromol. Rapid Commun. 2007, 28, 1792-1796. [CrossRef]

23. Zhang, N.; Schricker, S.R.; Wudl, F.; Prato, M.; Maggini, M.; Scorrano, G. A new $\mathrm{C}_{60}$ polymer via ring-opening metathesis polymerization. Chem. Mater. 1995, 7, 441-442. [CrossRef]

24. Ball, Z.T.; Sivula, K.; Fréchet, J.M.J. Well-defined fullerene-containing homopolymers and diblock copolymers with high fullerene content and their use for solution-phase and bulk organization. Macromolecules 2006, 39, 70-72. [CrossRef]

25. Biglova, Y.N.; Mustafin, A.G.; Torosyan, S.A.; Biglova, R.Z.; Miftakhov, M.S. Ring-opening metathesis polymerization (ROMP) of fullerene-containing monomers in the presence of a first-generation Grubbs catalyst. Kinet. Catal. 2017, 58, 111-121. [CrossRef]

26. Iwamoto, Y.; Yamakoshi, Y. A highly water-soluble $\mathrm{C}_{60}-\mathrm{NVP}$ copolymer: A potential material for photodynamic therapy. Chem. Commun. 2006, 4805-4807. [CrossRef] [PubMed]

27. Yamakoshi, Y.; Aroua, S.; Nguyen, T.M.D.; Iwamoto, Y.; Ohnishi, T. Water-soluble fullerene materials for bioapplications: Photoinduced reactive oxygen species generation. Faraday Discuss. 2014, 173, 287-296. [CrossRef] [PubMed]

28. Biglova, Y.N.; Mustafin, A.G.; Miftakhov, M.S. Physicochemical characteristics of the radical copolymerization of fullerene-containing methacrylates with vinyl monomers. Russ. J. Phys. Chem. B 2017, 11, 324-329. [CrossRef]

29. Drees, M.; Hoppe, H.; Winder, C.; Neugebauer, H.; Sariciftci, N.S.; Schwinger, W.; Schaffler, F.; Topf, C.; Scharber, M.C.; Zhu, Z.; et al. Stabilization of the nanomorphology of polymer-fullerene "bulk heterojunction" blends using a novel polymerizable fullerene derivative. J. Mater. Chem. 2005, 15, 5158-5163. [CrossRef]

30. Sivula, K.; Ball, Z.T.; Watanabe, N.; Frechet, J.M.J. Amphiphilic diblock copolymer compatibilizers and their effect on the morphology and performance of polythiophene: Fullerene solar cells. Adv. Mater. 2006, 18, 206-210. [CrossRef]

31. Miyanishi, S.; Zhang, Y.; Hashimoto, K.; Tajima, K. Controlled synthesis of fullerene-attached poly(3-alkylthiophene)-based copolymers for rational morphological design in polymer photovoltaic devices. Macromolecules 2012, 45, 6424-6437. [CrossRef]

32. Bai, Y.; Yao, X.; Wang, J.; Wang, J.L.; Wu, S.C.; Yang, S.P.; Li, W.S. Polymerizable $C_{70}$ derivatives with acrylate functionality for efficient and stable solar cells. Tetrahedron 2019, 75, 4676-4685. [CrossRef]

33. Nagashima, H.; Nakaoka, A.; Saito, Y.; Kato, M.; Kawanishi, T.; Itoh, K. C ${ }_{60}$ Pd: The first organometallic polymer of buckminsterfullerene. Chem. Commun. 1992, 377-379. [CrossRef]

34. Nagashima, H.; Nahaoka, A.; Tajima, S.; Saito, Y.; Itoh, K. Catalytic-hydrogenation of olefins and acetylenes over $\mathrm{C}_{60} \mathrm{Pd}_{\mathrm{n}}$. Chem. Lett. 1992, 21, 1361-1364. [CrossRef]

35. Brancewicz, E.; Grądzka, E.; Winkler, K. Comparison of electrochemical properties of two-component $\mathrm{C}_{60}-\mathrm{Pd}$ polymers formed under electrochemical conditions and by chemical synthesis. J. Solid State Electrochem. 2013, 17, 1233-1245. [CrossRef]

36. Leng, F.; Gerber, I.C.; Lecante, P.; Bacsa, W.; Miller, J.; Gallagher, J.R.; Moldovan, S.; Girleanu, M.; Axet, M.R.; Serp, P. Synthesis and structure of ruthenium-fullerides. RSC Adv. 2016, 6, 69135-69148. [CrossRef]

37. Goclon, J.; Winkler, K.; Margraf, J.T. Theoretical investigation of interactions between palladium and fullerene in polymer. RSC Adv. 2017, 7, 2202-2210. [CrossRef]

38. Zheng, D.Y.; Zhou, X.M.; Mutyala, S.; Huang, X.C. High catalytic activity of $\mathrm{C}_{60} \mathrm{Pd}_{\mathrm{n}}$ encapsulated in metal-organic framework UiO-67, for tandem hydrogenation reaction. Chem. A Eur. J. 2018, 24, 19141-19145. [CrossRef]

39. Sugawara, Y.; Hiltebrandt, K.; Blasco, E.; Barner-Kowollik, C. Polymer-fullerene network formation via light-induced crosslinking. Macromol. Rapid Commun. 2016, 37, 1466-1471. [CrossRef]

40. Chen, J.; Luo, K.; Zhu, J.; Yu, J.; Wang, Y.; Hu, Z. Reversibly cross-linked fullerene/polyamide composites based on Diels-Alder reaction. Compos. Sci. Technol. 2019, 176, 9-16. [CrossRef]

41. Zhou, H.; Zheng, Y.; Wang, X.; Tan, H.R.; Xu, J. Photoresponsive thermoelectric materials derived from fullerene- $C_{60}$ PEDOT hybrid polymers. ACS Appl. Energy Mater. 2020, 3, 6726-6734. [CrossRef] 
42. Karsten, B.P.; Bouwer, R.K.M.; Hummelen, J.C.; Williams, R.M.; Janssen, R.A.J. Charge separation and (triplet) recombination in diketopyrrolopyrrole-fullerene triads. Photochem. Photobiol. Sci. 2010, 9, 1055-1065. [CrossRef]

43. Jung, J.W.; Jo, J.W.; Jo, W.H. Enhanced performance and air stability of polymer solar cells by formation of a self-assembled buffer layer from fullerene-end-capped poly(ethylene glycol). Adv. Mater. 2011, 23, 1782-1787. [CrossRef]

44. Raïssi, M.; Erothu, H.; Ibarboure, E.; Cramail, H.; Vignau, L.; Cloutet, E.; Hiorns, R.C. Fullerene-capped copolymers for bulk heterojunctions: Device stability and efficiency improvements. J. Mater. Chem. A 2015, 3, 18207-18221. [CrossRef]

45. Isakova, A.; Burton, C.; Nowakowski, D.J.; Topham, P.D. Diels-Alder cycloaddition and raft chain end functionality: An elegant route to fullerene end-capped polymers with control over molecular mass and architecture. Polym. Chem. 2017, 8, 2796-2805. [CrossRef]

46. Vinogradova, L.V. Star-shaped polymers with fullerene $\mathrm{C}_{60}$ branching center. Russ. Chem. Bull. 2012, 61, 907-925. [CrossRef]

47. Samulski, E.T.; DeSimone, J.M.; Hunt, M.O.; Menceloglu, Y.Z.; Jarnagin, R.C.; York, G.A.; Labat, K.B.; Wang, H. Flagellenes nanophase-separated, polymer-substituted fullerenes. Chem. Mater. 1992, 4, 1153-1157. [CrossRef]

48. Ederlé, Y.; Mathis, C. Grafting of anionic polymers onto $\mathrm{C}_{60}$ in polar and nonpolar solvents. Macromolecules 1997, 30, 2546-2555. [CrossRef]

49. Xu, G.; Han, Y.; Sun, M.; Bo, Z.; Chen, C.J. Synthesis and characterization of star polyfluorenes with a $\mathrm{C}_{60}$ core. Polym. Sci. Part A Polym. Chem. 2007, 45, 4696-4706. [CrossRef]

50. Pulyalina, A.Y.; Rostovtseva, V.A.; Pientka, Z.; Vinogradova, L.V.; Polotskaya, G.A. Hybrid gas separation membranes containing star-shaped polystyrene with the fullerene $\left(\mathrm{C}_{60}\right)$ core. Petrol. Chem. 2018, 58, $296-303$. [CrossRef]

51. Pulyalina, A.Y.; Shugurov, S.M.; Larkina, A.A.; Faikov, I.I.; Tataurov, M.V.; Rostovtseva, V.A. Effect of star-shaped modifiers on the transport properties of polymer composites in the butan-1-ol dehydration process. Russ. J. Gen. Chem. 2019, 89, 2082-2091. [CrossRef]

52. Pulyalina, A.Y.; Larkina, A.A.; Tataurov, M.V.; Vinogradova, L.V.; Polotskaya, G.A. Hybrid macromolecular stars with fullerene $\left(\mathrm{C}_{60}\right)$ core included in polyphenyleneisophthalamide membranes for n-butanol dehydration. Fuller. Nanotub. Carbon Nanostruct. 2020, 28, 54-60. [CrossRef]

53. Liu, Y.; Wang, H.; Liang, P.; Zhang, H.-Y. Water-soluble supramolecular fullerene assembly mediated by metallobridged $\beta$-cyclodextrins. Angew. Chem. Int. Ed. 2004, 43, 2690-2694. [CrossRef]

54. Isla, H.; Pérez, E.M.; Martín, N. High degree of polymerization in a fullerene-containing supramolecular polymer. Angew. Chem. 2014, 126, 5735-5739. [CrossRef]

55. Hirao, T.; Fukuta, K.; Haino, T. Supramolecular approach to polymer-shape transformation via calixarene-fullerene complexation. Macromolecules 2020, 53, 3563-3570. [CrossRef]

56. Rao, A.M.; Zhou, P.; Wang, K.-A.; Hager, G.T.; Holden, J.M.; Wang, Y.; Lee, W.T.; Bi, X.-X.; Eklund, P.C.; Cornett, D.S.; et al. Photoinduced polymerization of solid $\mathrm{C}_{60}$ films. Science 1993, 259, 955-957. [CrossRef]

57. Iwasa, Y.; Arima, T.; Fleming, R.M.; Siegrist, T.; Zhou, O.; Haddon, R.C.; Rothberg, L.J.; Lyons, K.B.; Carter, H.L.; Hebard, A.F.; et al. New phases of $C_{60}$ synthesized at high pressure. Science 1994, 264, 1570-1574. [CrossRef]

58. Nuñez-Regueiro, M.; Marques, L.; Hodeau, J.-L.; Berthoux, O.; Perroux, M. Polymerized fullerite structures. Phys. Rev. Lett. 1995, 74, 278-281. [CrossRef]

59. Agafonov, V.; Davydov, V.A.; Kashevarova, L.S.; Rakhmanina, A.V.; Kahn-Harari, A.; Dubois, P.; Céolin, R.; Szwarc, H. 'Low-pressure' orthorhombic phase formed from pressure-treated $\mathrm{C}_{60}$. Chem. Phys. Lett. 1997, 267, 193-198. [CrossRef]

60. Le Parc, R.; Levelut, C.; Haines, J.; Davydov, V.A.; Rakhmanina, A.V.; Papoular, R.J.; Agafonov, V. In situ $\mathrm{X}$-ray powder diffraction study of one-dimensional polymeric $\mathrm{C}_{60}$ phase transformation under high-pressure. Chem. Phys. Lett. 2007, 438, 63-66. [CrossRef]

61. Blank, V.D.; Buga, S.G.; Dubitsky, G.A.; Serebryanaya, N.R.; Popov, M.Y.; Sundqvist, B. High pressure polymerized phases of $C_{60}$. Carbon 1998, 36, 319-343. [CrossRef]

62. Chernozatonskii, L.A.; Serebryanaya, N.R.; Mavrin, B.N. The superhard crystalline three-dimensional polymerized $C_{60}$ phase. Chem. Phys. Lett. 2000, 316, 199-204. [CrossRef] 
63. Talyzin, A.; Langenhorst, F.; Dubrovinskaia, N.; Dub, S.; Dubrovinsky, L. Structural characterization of the hard fullerite phase obtained at $13 \mathrm{GPa}$ and $830 \mathrm{~K}$. Phys. Rev. B 2005, 71, 115424. [CrossRef]

64. Pei, C.Y.; Feng, M.N.; Yang, Z.X.; Yao, M.G.; Yuan, Y.; Li, X.; Hu, B.W.; Shen, M.; Chen, B.; Sundqvist, B.; et al. Quasi 3D polymerization in C60 bilayers in a fullerene solvate. Carbon 2017, 124, 490-505. [CrossRef]

65. Yamanaka, S.; Kubo, A.; Inumaru, K.; Komaguchi, K.; Kini, N.S.; Inoue, T.; Irifune, T. Electron conductive three-dimensional polymer of cuboidal $\mathrm{C}_{60}$. Phys. Rev. Lett. 2006, 96, 076602. [CrossRef]

66. Laranjeira, J.; Marques, L.; Mezouar, M.; Melle-Franco, M.; Strutyński, K. Bonding frustration in the 9.5 GPa fcc polymeric $\mathrm{C}_{60}$. Phys. Stat. Sol. Rapid Res. Lett. 2017, 11, 1700343. [CrossRef]

67. Laranjeira, J.; Marques, L. $\mathrm{C}_{60}$ structures: Structural, electronic and elastic properties. Mater. Today Commun. 2020, 23, 100906. [CrossRef]

68. Brazhkin, V.V.; Lyapin, A.G.; Popova, S.V.; Klyuev, Y.A.; Naletov, A.M. Mechanical properties of the 3D polymerized, $\mathrm{sp}^{2}-\mathrm{sp}^{3}$ amorphous, and diamond-plus-graphite nanocomposite carbon phases prepared from $\mathrm{C}_{60}$ under high pressure. J. Appl. Phys. 1998, 84, 219-226. [CrossRef]

69. Pei, C.; Wang, L. Recent progress on high-pressure and high-temperature studies of fullerenes and related materials. Matter Radiat. Extrem. 2019, 4, 028201. [CrossRef]

Publisher's Note: MDPI stays neutral with regard to jurisdictional claims in published maps and institutional affiliations.

(C) 2020 by the author. Licensee MDPI, Basel, Switzerland. This article is an open access article distributed under the terms and conditions of the Creative Commons Attribution (CC BY) license (http://creativecommons.org/licenses/by/4.0/). 